\title{
El uso de los ancestros por la aristocracia castellana: el caso de los Ayala
}

El análisis de las señas de identidad de un Estado, forma de gobierno, sociedad o grupo humano constituye una de las líneas básicas de la historiografía de los dos últimos decenios. Su mayor desarrollo se ha dado en Francia, a través de la antropología histórica, que ya se había apuntado parcialmente en el interés por las mentalidades colectivas de la escuela de los Annales.

En consecuencia, por su componente simbólico se aproxima a los objetos de estudio de los antropólogos y se convierte en uno de esos puntos de diálogo, de aspiración interdisciplinar, en la práctica nunca realizada. Hay que reconocer que cada una de las ciencias sociales ha tomado forma en el seno de un contexto cultural e institucional muy particular, al que debe sus caracteres irreductibles ${ }^{1}$. Además, en nuestro país este diálogo se ve obstaculizado por la habitual falta de contactos entre los investigadores de distintas materias.

Entre los seguidores de los Annales más interesados en esta aproximación la vía adoptada comunmente ha sido tomar métodos, conceptos o temas del cuestionario etnológico o antropológico según sus propias necesidades $^{2}$. Y, más concretamente, para los medievalistas la pieza de arranque ha sido el clásico libro de Marc Bloch sobre la realeza de Francia e Inglaterra $^{3}$. Inspirándose en las tesis de Durkheim, postulaba la necesidad que tiene toda sociedad de unas creencias y representaciones compartidas para asegurar su cohesión. Con ello ponía de relieve el principio, tan caro al antropólogo, de la opacidad que caracteriza a toda realidad social.

1 Véanse a este respecto las observaciones realistas de Jacques REvEL en "Histoire et sciences sociales: una confrontation instablen, Passés recomposés. Champs et chantiers de l'histoire, dirección de Jean Boltier et Dominique Julia (Paris, 1995), pp. 69-82.

2 André BLRGLière, "L'anthropologie historique et l'École des Annales", en Historia a debate, t. III, Actas del Congreso Internacional "A Historia a debate" celebrado el 711 de julio de 1993 en Santiago de Compostela (ed. Carlos Barros, Santiago de Compostela, 1995), pp. 127-139.

3 Marc BLOCH, Les rois thaumaturges. Études sur le caractère surnaturel attribué a la puissance royale particuliérement en France et en Angleterre (1.. ed. Paris, 1924). 
Pero, realmente, la antropología histórica no posee un ámbito específico. Corresponde a un punto de partida que liga la evolución histórica a su resonancia social y a los componentes que la han engendrado o modificado ${ }^{4}$. En los momentos actuales, se encardina de manera primordial en la nueva historia política, el examen de los sistemas de parentesco y la historia cultural ${ }^{5}$.

Para la primera de estas disciplinas, el mito es un elemento de primer orden a la hora de abordar las diferentes formas de poder, sus aspectos imaginarios y la influencia que tienen en los mecanismos de legitimación y propaganda.

Por su parte, el enfoque del parentesco ve en la invención de un ancestro un procedimiento para glorificar el grupo familiar. Entre los siglos $\mathrm{x}$ al $\mathrm{XV}$, este grupo se concreta en el linaje como organización troncal que pone el acento en el fundador, de acuerdo con unas mentalidades colectivas aristocráticas.

Finalmente, la historia cultural presta creciente interés a "lo imaginario" y especialmente a la "construcción", "invención" o "constitución" de los hechos sociales, tales como la clase, la nación o el género ${ }^{6}$. Cuando este "imaginario" aparece registrado en un texto escrito, el objetivo del investigador es desvelar toda la complejidad de factores que participan en el triple proceso de elaborar, transmitir y acoger el ejemplar o su contenido. Así, se tiene en cuenta la incidencia en una determinada obra de la tradición oral, los cambios que suponen en ciertas épocas su inclusión en un vehículo culto como es el escrito, los préstamos legendarios de tipo erudito y el contexto general inmediato, y especialmente el político, social y religioso ${ }^{-}$. A su vez, todos estos ingredientes arrojan una pluralidad de lecturas que contribuyen a explicar los tiempos y modalidades de la difusión.

\footnotetext{
" André BUIRGUIÈRE, "L'anthropologie historique", en La nouvelle histoire, dirección de Jacques Le Goff, Roger Chartier y Jacques Revel (Paris, 1978), pp. 37-64.

5 Para los dos primeros campos de investigación, y centrado en la historiografía medieval francesa, resulta ilustrativo el estado de la cuestión de Jacques BERLIOZ, Jacques LE GOFF y Anita GuerREAU-JALABERT, "Anthropologie et histoire, en L'bistoire médiétale en France. Bilan et perspectives, coord. Michel BALARD (Paris, 1991), pp. 267305. 179 .

" Peter BuRke, "Varieties of cultural history", en La bistoria a debate, t. II..., pp. 175-

La mayoría de estas cuestiones son tenidas en cuenta por Roger CHARTIER en -Los ocasionales. La ahorcada milagrosamente salvada*, Libros, lecturas y lectores en la Edad Moderna (Madrid, 1993), pp. 203-246.
} 
Por tanto, el historiador ha de interpretar el mito aunando todos estos supuestos y desde las coordenadas que le son propias y que se pueden sintetizar en la importancia del plano diacrónico y de un asentamiento espacial modificado por la acción humana.

Ya se ha puesto de manifiesto que, a diferencia de lo que ocurría en la etapa positivista, la correspondencia de los datos con la realidad ya no constituye el criterio fundamental para definir el objeto histórico. Pero ello no significa que este contraste deje de ser pertinente. Incluso para las construcciones ficticias, se hace necesario considerar igualmente el plano real para poder deslindar las diferentes instancias por las cuales se recrea y transforma.

En definitiva, desde este objetivo global que postula hoy en día el quehacer histórico, el valor final que puede reportar un personaje u objeto ficticio no puede ser entendido en toda su complejidad si no se contempla al mismo tiempo su composición interna y los motivos que le condicionan y contribuyen a crearlo. Dicho de otra manera, las causas, modos y fines operan en este punto como una cadena de eslabones inseparables e interdependientes.

En el caso concreto que se expone aquí, mi propósito es presentar un trabajo de "micro-historia" en el cual la suma de indicios permita proponer un modelo para interpretar los fundadores imaginarios de las grandes Casas nobiliarias castellanas ${ }^{8}$. Hay que reconocer, sin embargo, que la escasez de relatos pormenorizados para la trayectoria de la mayoría de los linajes no permite, en el estado actual de nuestros conocimientos, verificar este modelo salvo en sus líneas más generales. No obstante, la unión de algunos principios teóricos con hipótesis elaboradas en el curso del trabajo posibilita el adelantar las siguientes premisas:

- El énfasis que la nobleza medieval pone en sus ancestros se corresponde con un parentesco organizado en linajes y un poder basado en dominios estables y, en esencia, inalienables y hereditarios. Esta jerarquía y continuidad familiar resultan imprescindibles para que los magnates o los letrados a su servicio puedan reflexionar sobre el papel de la estirpe

\footnotetext{
* A nivel metodológico, no se puede dejar de recordar el "paradigma indicialn que C. Ginzburg propone como modelo epistemológico de las ciencias humanas, basándose en diversos ensayos de Freud. Pero el historiador italiano pone el acento en los datos marginales considerados reveladores: Carlo GINZBURG, .Indicios. Raíces de un paradigma de inferencias indiciales", en Mitos, emblemas, indicios. Morfologia e bistoria (Barcelona, 1989), pp. 138-176. Aquí habría que sumar a estas referencias secundarias las que pueden erigirse como distintivas de toda la literatura genealógica medieval, y las que han de adscribirse más especialmente al tiempo y el espacio en los que ha sido redactada la fuente en la que se basa la investigación.
} 
en el colectivo de sus iguales. En la Corona de Castilla, este discurso no se constata claramente hasta mediados del siglo XIV, con el advenimiento de la dinastía Trastamara y la consolidación de los señoríos plenos.

- Los antepasados fundacionales registrados en memorias y nobiliarios pueden ser constatables o ficticios. Estos últimos suelen utilizarse por estirpes secundarias, recién llegadas a la política, que se esfuerzan en hacer olvidar así sus oscuros comienzos. Pero, en ambos casos reunen unas características que, con ligeras variantes, son comunes a todo el Occidente europeo. Están fundamentadas en la antigüedad, los lazos de parentesco, el cumplimiento de la función social de la nobleza y, secundariamente, el poder, los vínculos con el soberano, la riqueza y las virtudes cristianas.

- El optar por un personaje que no pueda ser constatado requiere una distancia cronológica de, al menos, unos 150 ó 200 años entre su presunta trayectoria vital y la realidad contemporánea de quien la describe. Solo así puede ubicarse en un pasado lejano que traspase la memoria visual o auditiva. Esta última fundamenta otro mecanismo legitimador muy frecuente en la Edad Media, pero que, en cierta manera, se contrapone a lo imaginario: el concepto de "lo público y notorio" para acontecimientos inmediatos o del pasado reciente. Además, hay que tener en cuenta que los esfuerzos de documentar los ascendientes en torno a las dos centurias se verían, en general, frustrados en una época en que únicamente se acostumbraban a archivar durante varias generaciones los títulos de propiedad más importantes. De hecho, únicamente las vicisitudes de los magnates y caballeros a los que se dedicaba amplio espacio en las crónicas podían ser dignificadas por un respaldo erudito y textual.

- La elaboración de un ancestro ficticio parte de un trasfondo a la vez real y legendario. Ambos aspectos tienen la finalidad de enraizar a la familia en el territorio donde se asienta el dominio. Sin embargo, la importancia del segundo está vinculada directamente a que los temas en los que se basa sigan manteniendo su aceptación en el conjunto de la sociedad o de las élites aristocráticas. Por tanto, algunas figuras presentadas como fundadoras de linajes procedieron casi enteramente de tradiciones anteriores, independientemente de que fueran conservadas de forma oral o escrita, mientras que otras solamente tomaron referencias secundarias.

- La manipulación del pasado que supone la existencia de estos antepasados míticos no se reduce a un acto consciente para afirmar el prestigio de los señores contemporáneos al texto a través de las cualidades de sus antecesores. En primer lugar, se advierte un afán de veracidad en todos los autores de los siglos centrales y postreros de la Edad Media, aunque sólo se lleve a la práctica parcialmente, debido al empleo de 
fuentes no contrastadas. Pero es que además se trata de una distorsión muy compleja, que opera a varios niveles: el ajuste a las características que deben adornar a un cabeza de linaje para ser considerado como glorioso, los cambios experimentados en los modelos nobiliarios a través del tiempo y el espacio, las diferencias entre la sociedad y la organización del parentesco del supuesto período fundacional y la de la etapa en la que se registra la historia del grupo familiar, la tipología formal y la modalidad concreta de cada escrito genealógico y, finalmente, la personalidad del autor y sus posibles vínculos de consanguineidad, afinidad o crianza con los personajes descritos o sus descendientes.

En las páginas siguientes, se abordarán estos problemas más pormenorizadamente, insertándolos en la evolución general del Occidente europeo. Sin esta alusión a un entorno más amplio, las peculiaridades de la Historia de los territorios occidentales hispánicos no pueden ser comprendidas cabalmente.

\section{LA LITERATURA GENEALÓGICA MEDIEVAL}

Al igual que sucede en colectividades de otros espacios y períodos históricos, la consolidación plena de las élites medievales lleva aparejada la conciencia de su especificidad, ya se plasme a través de las manifestaciones de sus propios miembros o de las de escritores y artistas ligados a círculos cortesanos. En el caso de la aristocracia, se expresá básicamente en la literatura genealógica y, en menor grado, en la memoria de los propios señores.

Con respecto al occidente europeo -y, más concretamente, los territorios de Flandes, centro y norte de Francia y Alemania - las primeras noticias genealógicas datan de mediados del siglo $\mathrm{x}$. Se trata, sin embargo, de un testimonio aislado que no tiene continuidad hasta las décadas centrales de la siguiente centuria. Entre 1160 y el primer tercio del siglo siguiente es cuando este fenómeno adquiere especial intensidad, en consonancia con la constitución de los grandes principados. En este último período, es cuando este género de la historia familiar se abre, además, a la estirpe regia francesa y a la de magnates de menor envergadura".

En cuanto a los recuerdos de los nobles sobre sus propios parientes se constatan en la Francia central y meridional y en Cataluña a partir

9 Georges Duby, "Estructuras de parentesco y nobleza en la Francia del norte en los siglos XI y XIIn y .Observaciones sobre la literatura genealógica en Francia en los siglos XI y XII", en Hombres y estructuras de la Edad Media (Madrid, 1978), pp. 162-198. 
de 1090. Se plasman fundamentalmente en breves textos autobiográficos, canciones poéticas, misivas y, más secundariamente, en documentos concernientes a querellas y herencias, en los cuales la inclusión de argumentos personales tienen como finalidad justificar un enfrentamiento familiar o un reparto de bienes. Su contenido no rebasa la memoria humana: se centra en las propias vivencias, en las de colaterales contemporáneos de la generación precedente o inmediata y, menos frecuentemente, en la actividad de los antecesores en segundo grado, es decir, tíos maternos y paternos, sobrinos y abuelos. Resultan una fuente de gran utilidad para conocer el funcionamiento de los vínculos de parentesco y el modo en el que eran percibidos por los autores de estos testimonios ${ }^{10}$.

Entre 1300 y 1530, el interés del Occidente europeo por la historia familiar se enriquece con nuevos elementos: la emergencia de nuevos sectores a la cúspide social, el valor concedido progresivamente a lo individual y cotidiano y la difusión de la escritura más allá de los círculos señoriales y eclesiásticos explican, entre otros factores, la existencia de un renovado interés por registrar los acontecimientos vitales propios y de los ascendientes inmediatos y, al mismo tiempo, por la elaboración de genealogías de más largo alcance. Su expresión más acabada son los libros de ricordanze florentinos, que en gran abundancia escriben los representantes de la élite de comerciantes y caballeros urbanos con el fin de transmitir el pasado familiar a sus descendientes. Y un reducido número de obras de este género, compuestas usualmente por miembros de la nobleza, buscan sistemáticamente el conjunto de lazos de filiación para establecer genealogías que sustenten derechos privados $\mathrm{o}$, ya en el siglo $\mathrm{xv}$, la antigüedad del linaje y de su implantación en la ciudad ${ }^{11}$.

En los territorios que formaron la Corona de Castilla, en cambio, no se constatan claramente estos dos tipos de reivindicación del pasado hasta la Baja Edad Media y, sobre todo, hasta las postrimerías del siglo XIV. En contra de lo que pudiera concluirse a primera vista, la causa no reside en un tardío arraigo de estos fenómenos generales sino en el carácter diferencial de la historia castellana: el control de la autoridad regia sobre los señores, debido a la calidad básica del soberano de jefe guerrero contra el Islam hispano, posibilitó que los principados señoriales fueran muy escasos y sólo con carácter excepcional tuvieran atribuciones plenas. Al mismo tiempo, la fuerte persistencia de los rasgos bilaterales y la filiación

\footnotetext{
11) Jose Enrique Rliz Domenec, La memoria de los feudales (Barcelona, 1984).

1 Christiane KLAPISCH-ZLBER, "L'invention du passé familial. y "Le travail généalogique., en el compendio de trabajos de esta autora La maison et le nom. Stratégies et rituels de la Renaissance (Paris, 1990), pp. 5-59.
} 
materna y la adopción muy temprana de un derecho escrito -el Liber Iudiciorum visigótico- que instituía un reparto esencialmente igualitario de la herencia contribuye a explicar la ausencia durante la Plena Edad Media de una transmisión patrimonial claramente establecida por vía de primogenitura $y$, en esencia, inalienable ${ }^{12}$.

La consecuencia de todo ello es la fragmentación de los patrimonios aristocráticos y la falta de estructuras familiares de linaje que lleven aparejadas una conciencia de jerarquía troncal del parentesco. Será hacia 1250 cuando se comience a constatar la pervivencia de bienes y cargos durante generaciones y especialmente a partir de los años finales de la siguiente centuria, con el otorgamiento de señoríos plenos por la dinastía Trastamara y la adopción del régimen de mayorazgo ${ }^{13}$.

No es de extrañar, entonces, que hasta la Baja Edad Media no existan genealogías castellanas surgidas del círculo de los señores laicos. En efecto, los escasos ejemplos de los siglos $\mathrm{x}$ al xiI proceden de fuentes monásticas y tienen como finalidad probar los derechos de una abadía sobre las propiedades donadas por los personajes a los que se menciona. De todas formas, se observa una cierta evolución entre 1230 y 1260 , aproximadamente, y que se puede sintetizar en que la cadena de ascendientes tiene una ampitud mucho mayor que las cuatro generaciones que, por término medio, se recogen en los siglos precedentes ${ }^{14}$.

12 Me refiero en este párrafo concreto al período comprendido entre los anos centrales de los siglos $\mathrm{x}$ al XIII, aproximadamente.

13 Para la evolución de las estructuras de parentesco castellanas durante la Plena y Baja Edad Media véase Isabel BECEIRO PITA y Ricardo CÓRD(IBA DE LA LLAVE, Parentesco, poder y mentalidad. La nobleza castellana, siglos XII-XV (Madrid: CSIC, 1990).

${ }_{1+}$ La fuente más extensa está constituida por el Tumbo de Santa María de Sobrado, que contiene nueve relaciones breves, varias de ellas enlazadas entre sí, como las concernientes a los Traba. Resulta insólita la memoria de los fundadores del monasterio de Santa María de Ferreira de Pallares, también enclavado en tierras lucenses: debió de elaborarse entre 1238 y 1262 y expone los hitos de la estirpe durante un período

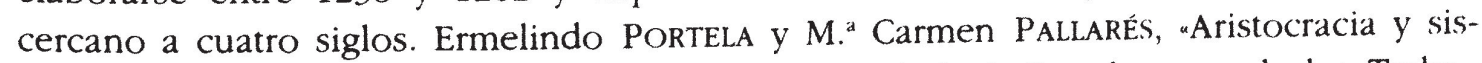
tema de parentesco en los siglos centrales de la Edad Media: el grupo de los Traban, en el compendio de trabajos de estos dos autores De Galicia en la Edad Media. Sociedad, Espacio y Poder (Santiago de Compostela, 1993), pp. 293-294; Carlos SÁEz y M. ${ }^{a}$ Jesús VÁzQuez MADruga, "Genealogías del monasterio de Sobrado (s. X-XI)", en Carlos SÁEZ y Joaquín GÓMEZ-PANTOJA (ed.), Las diferentes historias de letrados y analfabetos (Alcalá de Henares, 1994), pp. 39-54 y Jaime de SALAZAR ACHA, "Los descendientes del conde Ero Fernández, fundador del monasterio de Santa María de Ferreira de Pallares", en Galicia en la Edad Media (Madrid, 1990), pp. 67-87. 


\section{El teXto de Fernán PÉrez de Ayala sobre sus ascendientes}

El primer escrito conocido en el que un miembro de la nobleza registra toda la serie de antepasados desde el ancestro fundador hasta su realidad contemporánea es precisamente el que constituye el objeto de este estudio. Se trata del Libro del linaje de los señores de Ayala, desde el primero que se llamó D. Vela hasta mí D. Fernán Peres, redactado en 1371 por el padre del famoso canciller don Pero López de Ayala ${ }^{15}$. Tiene el interés, además, de aunar este género de historia genealógica con el ya aludido de fijar el recuerdo y exaltar el propio linaje a través de la trayectoria anterior. En esta segunda vertiente, enlaza con otras obras que en ese mismo siglo emplean por primera vez un fuerte tono autobiográfico para referirse al autor, sus padres y sus abuelos. Al contrario que en Italia, son escasas y no rebasan el ámbito nobiliar. Su finalidad es reivindicar una especial consideración dentro de los ligados al soberano por lazos de sangre, en el caso del Libro de las tres razones de don Juan Manuel, y contraponer el espejo positivo de la preponderancia política del padre a las penalidades pasadas por la protagonista, sus progenitores y hermanos tras la caída en desgracia, en las Memorias de doña Leonor López de córdoba, que se integran en sentido amplio en el tema de la "rueda de la fortuna" ".

Pero el escrito de Fernán Pérez responde a una situación diferente en la escala nobiliar: la trayectoria de los Ayala, entendida como tal a partir del momento en que se fija este renombre hereditario, era relativamente reciente, pues únicamente contaba con unos 150 años de antigüedad a partir del primer Pero López de Ayala, participante en las conquistas de Bateza y Sevilla bajo las órdenes de Fernando III. Además este personaje

1. Para la actividad intelectual de Fernán Pérez de Ayala, en conexión con la de otros miembros de la familia y con la de su célebre hijo, véase Michel Garcia en La formacion de Alata. 050 Anicersario del Pacto de Arriaga (1322-1982). Congreso de Estudios Historicos (Vitoria-Gasteiz, 1984), pp. 167-179

16 Don Juan Manuel, Obras completas, t. I, ed. de Jose Manuel Blecua (Madrid, 1982), pp. 117-141. (Utilizo aquí la denominación de Libro de las tres razones por preferirla los criticos actuales a la tradicional de Libro de las armas). R. AYERBE-CHALX. "Las memorias de dona Leonor López de Córdoba", Joumal of Hispanic Philology, 2 (1977), pp. 22-23 y Arturo R. FIRPO, "L'idéologie du lignage et les images de les familles dans les "Memorias" de Leonor López de Córdoba (1400). Le Moyen Age, t. 87, n. 2 (1981), pp. 243-263. Para la progresiva implantación de la literatura genealógica en el reino castellano, véase Isabel BECEIRO PITA, "La conciencia de los antepasados y la gloria del linaje en la Castilla bajomedieval, en Reyna PASTOR (Comp.), Relaciones de poder. de produción y parentesco en la Edad Media y Moderna (Madrid: CSIC, 1990), pp. 329-351. 
desciende por línea paterna de una de las grandes Casas de la Plena Edad Media castellana, la de los Haro, señores de Vizcaya ${ }^{1}{ }^{7}$. Por último, los Ayala no alcanzan una posición de primer rango político-social hasta finales del siglo XIV y comienzos del XV, es decir, bajo el mandato del propio genealogista y su primogénito, y ésta es, sin duda, la razón de que Moxó los excluya de su panorama general sobre la "nobleza vieja" ${ }^{1 *}$. En consecuencia, y como luego se verá, el autor utiliza, en sus líneas básicas, los mismos procedimientos de exaltación del linaje que habían presidido escritos similares del Occidente y, que en el siglo xv se prolongan en los nobiliarios castellanos, en muy estrecha afinidad con lo entrevisto aquí. Los principales se pueden sintetizar en el afán de dotar de antigüedad a la fundación de la Casa y situar su ancestro originario en un personaje de sangre real o un noble que haya adquirido fama en las grandes gestas que configuran la historia del reino o principado donde se asientan sus terrritorios, o bien en las grandes empresas de defensa del conjunto de la cristiandad, como las cruzadas, o, en el plano mítico, la búsqueda del Santo Grial. A ello se superponen, en ocasiones, elementos que pueden provenir de leyendas populares de raíz pre-cristiana.

Con todo, a mi entender, los indudables errores históricos que encierran estos relatos no están motivados por un designio deliberado de falsificar la realidad sino, en buena parte, por confusiones basadas en etimologías simplistas al modo de las elaboradas por San Isidoro y por la adopción indiscriminada de una amalgama de tradiciones locales. Fvidentemente, el escritor adopta preferentemente lo que más contribuye a la gloria de un grupo familiar o de la totalidad de la nobleza, pero la misma inclusión de poemas épicos en la Primera crónica general de Alfonso $X$ el Sabio muestra que en la Edad Media no existe una conciencia de que la Historia y el cantar de gesta constituyan dos géneros completamente diferentes, de los cuales solamente el primero goza de un status científico.

1- Rafael Floranes en sus "Memorias familiares, militares y políticas del canciller Pero López de Ayala", Colección de Documentos Inéditos para la Historia de España, t. XIX (Madrid, 1851, reimpresión, Vaduz, 1966), pp. 34-35, pone énfasis en que constituyen una rama segundona masculina de los Haro. Se apoya para ello equivocadamente en las manifestaciones del canciller, cuando en realidad pertenecen a su padre.

is Me refiero al tan conocido artículo de Salvador DE MOXó, "De la nobleza vieja a la nobleza nueva. La transformación nobiliaria castellana en la Baja Edad Media", Cuadernos de Historia. Anexos de la revista Hispania, 3 (1969), pp. 1-120. Fn él se establece la contraposición entre una nobleza surgida entre los siglos XI y XII y otra que la sustituye a mediados del XIV, con la llegada al poder de la dinastía Trastamara. La investigación actual pone en duda que esta diferencia sea tan tajante, ya que buena parte de los nuevos linajes proceden de colaterales () afines de los anteriores. 
Únicamente a partir de la época del primer humanismo se pueden advertir ciertos intentos parciales de depurar las fuentes en este sentido.

\section{LOS PROBLEMAS EN LA TRANSMISIÓN POSTERIOR DE ESTE TEXTO}

Nuestro conocimiento actual no procede de la fuente original, ni siquiera de versiones medievales posteriores. Únicamente ha pervivido por entero a través de una copia que se puede datar aproximadamente en el primer tercio del siglo Xvill, pero que, a su vez, reproduce y anota otra anterior en unos cincuenta años y que proclama haber cotejado un traslado autentificado del documento. Más concretamente, es Luis de Salazar y Castro quien transcribe esta obra, añadiéndole un prólogo en el que confiesa haberla encontrado entre los papeles de Joseph Pellicer de Tovar y Ossau que le proporcionó su nieto, don Pedro Pellicer de Tovar ${ }^{19}$. El prefacio que el propio Pellicer tenía, previsiblemente, asignado como portada titula a este tratado "Árbol verdadero de la Casa de Ayala, que consta del libro de su genealogía, que escrivio hasta su tiempo D. Fernan Perez de Ayala... señor y continuo el Chanciller maior D. Pedro Lopez de Aiala su hijo y sucesor en ella..." Revela, además, en otro apartado adicional el carácter utilitario de su proyecto: realizar una publicación comentada en obsequio de sus contemporáneos del linaje de los Ayala, del titular por entonces de la Casa y VI conde de Fuensalida, que le había entregado los soportes documentales, y del mismo rey Felipe IV, emparentado lejanamente con los Ayala. Realmente, su propósito no difería en modo alguno del de tantos escritores medievales a los que se califica modernamente de serviles a la nobleza.

Ahora bien, si no existieran otros indicios de su existencia cabría dudar de la autenticidad del Libro del linage de los Señores de Ayala pues, como ha señalado Caro Baroja, parte de la producción de Pellicer se integra en la serie de fraudes históricos del siglo Xvil español, que se conoce como los "falsos cronicones" 2". En efecto, llegó a forjar uno supuestamente escrito por Servando, que habría sido confesor del último rey godo, después de don Pelayo y, finalmente, canónigo y obispo de Orense. En la misma obra analizada aquí el discutido historiador ha enmendado varias

10 Se halla en la actualidad en la Real Academia de la Historia. Colección Salazar y Castro, B-98, fols. 1-1 v. Salazar vivió entre 1657 y 1734 y Joseph Pellicer de 1602 a $10^{-9}$.

20 Julio CARO BAROJA, Las falsificaciones de la bistoria (Barcelona, 1992), pp. 104105 . 
veces el texto o añadido sus personales interpolaciones. Algunas de ellas ya han sido puestas de manifiesto por Salazar y, en 1950, por el marqués de Lozoya, al editar el documento en su apéndice a una breve biografía del canciller ${ }^{21}$. Se pueden sintetizar en retrotraer parcialmente las estructuras bajomedievales de linaje a los siglos XI y xII, en los que predominaba la parentela, mediante la acentuación del papel de los primogénitos en detrimento del de hermanos y segundones, y, por otra parte, en resaltar la importancia de algunas Casas menores, a las que él se hallaba vinculado.

Estas dudas quedan salvadas, en lo esencial, por la referencia en las Generaciones y semblanzas de Fernán Pérez de Guzmán al escrito de su casi homónimo abuelo y al personaje proclamado en él como primer ancestro de los Ayala ${ }^{22}$. Además, entre 1471 y 1475 Lope Garcia de Salazar siguió con todo detalle esta genealogía en sus Bienandanzas y fortunas, aunque abreviando los datos sobre los Guevara y algunas estirpes afines de menor rango ${ }^{23}$. Por último, dentro de las sucesivas memorias de su parentesco, registradas por varios de los Ayala, es considerada como un eslabón entre la presunta semblanza inicial elaborada por Sancho García el Cabezudo en el siglo XIII, la Relacion fidelisima de las sucessiones del linage de Ayala, confeccionada a mediados del xv por Pedro lópez de Ayala,bisnieto de nuestro tratadista ${ }^{24}$, y un nuevo escrito del mariscal García López de Ayala, contemporáneo al de Lope García de Salazar, que se hace eco de éste del padre del canciller ${ }^{25}$.

El objetivo de este estudio es analizar el Libro del linage de los señores de Ayala en cuanto exponente de las pautas que presiden en la Baja Edad

21 Introducción a la biografía del canciller Ayala, con prólogo de don Javier DE. YBARRA Y BERGÉ y apéndices documentales recogidos por don Juan 1PE ConTRERAS Y LÓPEz DE AYALA, marqués de Lozoya (Bilbao, 1950).

22 Fernán PÉREz de GuZMÁN, Generaciones y semblanzas ( $\mathrm{ed}$. de J. Domíngue'z. Bordona, Madrid, 1979), pp. 37-38. Hay que recordar que este volumen fué redactado entre 1450 y 1455.

23 Lope GARCía DE SALAZAR, Las bienandanzas e fortunas red. de Ángel Rodríguez Herrero, t. IV, Bilbao, 1967), pp. 35- 36. A estas páginas acerca de los Ayala propiamente dichos hay que añadir las referentes a las Salcedo y a los Guevara, pp. 36-4() y pp. 30-31, respectivamente.

24 Ha sido publicada por Luis DE SALAZAR y CASTRO en Pruebas de la historia de la Casa de Lara (Madrid, 1694), pp. 56-61. La homonimia del conde de este autor con su famoso abuelo es, muy probablemente, la causa de haberlas atribuido erróneamente a literato.

25 Introducción a la biografía del canciller Ayala, p. 17 y Rafael FLORANEs, "Vida literaria del Canciller Mayor de Castilla", Colección de Documentos Inéditos para la Historia de España, t. XIX, ... pp. 155-158. No me ha sido posible consultar esta última genealogía. 
Media castellana la elaboración de genealogías y, sobre todo, preludio de los antepasados míticos preferidos en ellas. En segundo lugar, un conciso panorama de las variantes introducidas en el siglo XV permitirá ver, a la vez, los cambios en la mentalidad nobiliar con respecto al período precedente y la utilización de la historia de Fernán Pérez por descendientes lejanos o inmediatos.

Evidentemente, el uso de esta fuente se prolonga a la Edad Moderna. Sus causas residen, igualmente, en la mentalidad del conjunto de la nobleza, de la que participa Pellicer, y en el aprovechamiento interesado que realiza el círculo familiar. Pero la gran complejidad ideológica de la primera fase del Antiguo Régimen español y el incremento documental me lleva a relegar este último período.

\section{LOS ELEMENTOS BÁSICOS DE LA OBRA}

Abarca un período comprendido entre finales del siglo XI y el acceso al señorío del escritor. Carece de datación cronológica, salvo una aislada que abre el comienzo de la titularidad de Sancho Pérez de Ayala, hermano $y$ antecesor inmediato, y se corresponde con la etapa límite de los cuatro decenios, que se esgrime usualmente en la época dentro de las querellas judiciales para dirimir disputas sobre propiedades y derechos ${ }^{20}$. En efecto, la fecha marcada es la de 1330. por tanto, cuarenta y un años anterior a del manuscrito. En torno a ella cabe situar las expresiones que indican el recuerdo personal: "e acaescieron muchas peleas entre los parientes, de que yo muy bien me recuerdo"... "vna muy noble dueña [...] la qual yo conoci en Aragón" "-

Más allá, se puede extender hasta principios de la centuria la conciencia del parentesco inmediato, plasmada en que los personajes que se mencionan son caracterizados por su relación familiar con el autor: abuelo paterno, progenitores y tíos de ambos sexos y hermano. Coincide, además, con el momento en que los Ayala pasan a primer plano político y toman el relevo de los Salcedo en el señorío del que procede su renombre.

Pero las referencias temporales de otro tipo son abundantísimas en el texto. Se basan en las grandes hazañas guerreras de la monarquía caste-

2. Para las referencias temporales basadas en decenios y reinados y sus fundamentos ideológicos y juridicos, véase Isabel BECEIRO PITA, "La memoria de las propiedades y derechos senoriales: las posesiones del Cister gallego-leonés en el norte de Portugal (1258-1305)", Temas mediezales, 2 (Buenos Aires, 1992), pp. 15-35.

$=\quad$ RAH. Col Salazar, B-98, fol. 8 y fol. 11. 
llana y, en menor grado, de las otras peninsulares, en los cargos disfrutados al servicio de la Corona y, esporádicamente, en las transformaciones políticas de los reinos hispánicos. Aparte de adecuarse mejor a períodos distantes del contemporáneo a quien escribe, responden a un propósito explícito, el de vincular la gloria del linaje con la de la monarquía y la misma divinidad, por el doble carácter de cruzada y servicio regio que podían revestir los hechos de armas contra el Islam. Está formulado en las palabras del relato que siguen al título: "que le fiz a honrra e gloria de Dios, e pro de mio linage, e para que sean buenos e homildes e sirvan a Dios, e al Rey los que de mi vinieren".

Hay que tener en cuenta, igualmente, que a finales del siglo xiv comienza a tomar carta de naturaleza en el territorio castellano el sentimiento de la existencia de una doble vía de acceso a la nobleza, inspirado en las doctrinas del jurista italiano Bartolo de Saxoferrato: la sangre y, en consecuencia, la antigüedad y posición de los antepasados en la aristocracia, y, por otra parte, las buenas obras, ya se concreten en labores administrativas, militares o funciones de letrado para los soberanos. Y resulta un mecanismo habitual en las genealogías hispánicas que cuando se sitúa como piedra angular de su importancia un ancestro cuya credibilidad puede no ser unánimente admititida se presente otro antepasado adicional de refuerzo, que proporcione aceptación a una parte o a la totalidad de la estirpe 28 . En este caso podrían enmarcarse, como después se verá, los Ayala.

En cuanto a la estructura del texto, está determinada por tres principios: la capacidad de establecer alianzas matrimoniales y acceder a señoríos, el papel autónomo con respecto a otros linajes aristocráticos y la procedencia regia de los ancestros. En consecuencia, los datos se organizan a partir de varios grupos de parentesco, que recogen las líneas paterna y materna del autor. El primero - como corresponde a la conciencia del linaje de fines del siglo XIV - es el que recibe un tratamiento de mayor relevancia y adopta una estructura más compleja: los Ayala son presentados como el producto de la unión de dos grupos de parentesco, los Salcedo y los Guevara, cada uno de los cuales cuenta con una figura prestigiosa originaria y diversos segmentos familiares, que se destacan en cada generación en virtud de sus propiedades territoriales y la importancia

28 Así, en el Livro de linhagens del conde don Pedro DE PORTUGAL, elaborado entre 1340 y 1344 , y que recoge gran cantidad de fuentes y tradiciones castellanas, se hace descender a los señores de Vizcaya de tres tipos de ancestros, uno primario y otros dos, que se adscriben a fondos míticos diferentes, en la segunda y cuarta generación. Portvgaliae Monvmenta Historica, nova serie, volume II/1, Livro de Linbagens do Conde D. Pedro (ed. de José Mattoso, Lisboa, 1980), título IX, pp. 137-139. 
de los vínculos de afinidad establecidos. En el plano formal, tiene como resultado una narración farragosa al incorporar las trayectorias particulares de cada uno de estos segmentos, difícil de seguir por las consiguientes rupturas temporales y, en definitiva, bastante confusa si no se reduce a sus líneas esenciales.

Dentro de ambos grupos, los Salcedo constituyen el tronco directo por vía masculina. En el relato de Fernán Pérez, se traduce en el afán de otorgar un mayor prestigio a esta estirpe relativamente oscura. En principio, se consigue por la mayor atención dedicada a la trayectoria de su fundador que a la del primero de los Guevara. Pero además, puede advertirse una cierta tendencia a difuminar su carácter subsidiario frente a los señores de Vizcaya en base a la ausencia, en general, de epítetos encomiásticos en torno a los Haro mencionados y, sobre todo, de omitir toda referencia a los orígenes de este linaje.

En cambio, las señales heráldicas se utilizan para enaltecer tanto a los Salcedo como a los Guevara. Se detallan aquí profusamente, ligándolas a la constitución de algunos dominios en la Plena Edad Media, aun cuando se trate de formas y tipos de emblemas que no se atestiguan, en realidad, más que en las décadas inmediatas al escrito ${ }^{29}$. Hay que enmarcar este anacronismo en una transposición inconsciente al pasado de las estructuras del momemto en el que es evocado, y que se advierte igualmente en otros temas. Pero a ella se superpone un designio deliberado de presentar las diferentes ramas como Casas aparte y con distintivos específicos, a ejemplo de la forma en la que se organizaba la cúspide aristocrática bajomedieval.

Con todo, la piedra angular del enaltecimiento de los Ayala, tal y como lo exhibe Fernán Pérez, reside en el antepasado que se sitúa como origen de su línea paterna, don Vela, y, en menor medida, en ese ancestro secundario de la misma línea, don Ladrón, señor de Guevara. Como se verá inmediatamente, algunas de las características que uno y otro revisten son comunes a la mayoría de las genealogías nobliarias, sobre todo las que conciernen a linajes de la pequeña y media nobleza recién llegados a la élite socio-política: a este respecto, la integración en la sangre real de dinastías antiguas del reino o, en menor grado, de la Europa continental, resulta lo más destacable y reiterado. Otros elementos pueden responder a una valoración de época, como la reputación de santidad de algunas figuras en el siglo xIv. Un tercer tipo de pautas puede estar ligado al

29 Así, se presenta al conde don Pero Ladrón adjudicando en la primera mitad del siglo XIII a su hijo Martín Pérez la banda negra de los Guevara, que no está constatada por otras fuentes hasta mediados de la centuria siguiente. Agradezco a don Faustino Menéndez Pidal sus observaciones sobre éste y otros aspectos heráldicos, así como sus ayudas bibliográficas. 
territorio de asentamiento principal del señorío en cuanto a las normas específicas de comportamiento del sector nobiliar, las tradiciones locales y los contactos exteriores a todos los niveles; en este caso, cabría hablar de Álava como zona de cruce entre las aportaciones culturales castellanas y vascas y, en el terreno político, sometida al doble influjo de Castilla y Navarra. Finalmente, algunos rasgos pueden introducirse o no según pertenezca el autor al grupo de parentesco reseñado, por el contrario, se englobe entre los tratadistas externos a él. Al primer supuesto puede responder en el tratamiento de don Vela su filiación legítima del rey aragonés Sancho Ramírez y una suerte de prohijamiento posterior por parte de Alfonso VI de Castilla y León.

\section{El INFANTE DON VELA, FUNDADOR DE LOS AYAlA}

En tiempo del Rey D. Alfonso que ganò a Toledo vino aqui ala su merced un fijo del Rey D. Sancho de Aragon el que finò sobre Guesca. E este Infant seiendo el mas pequeño de sus hermanos fino ende el primero. E este tal se decie D. Vela y era mui buen mancebo, e el Rey D. Alfonso, pagosse del, e criole, e fizole cauallero en Burgos, e prometiole que lo heredaria e daria naturaleza ensu Reino. Epor $\mathrm{t}(\mathrm{iem})$ po el Rey D. Alfonso vino entierra de Losa, e parosse atomar huelgo sobre la peña que era enderecho onde agora es Ayala. E viendo que era toda Montes, e Valles, pregunto alos suios de cuio señorio era aquella tierra. F digeronle que era Realenga. E algunos que eran hi amigos de D. Vela, dijieronle que la pidiesse alRey e el pidiola, e dijol enesta guissa: Señor bien sabedes que me prometistes de me dar naturaleza, e me heredar en vuessa tierra. Pido vos por m(e)rc(e)d que la v(uest)ra merced sea de me dar estos Montes, e yo poblar los he, e defender los he contra todos los homes del Mundo; salvo contra vos. E los que estavan hi que habian sabor dele ayudar dixieron: Señor Ayala. Y el Rey dijo que leplacia e que oviesse este nombre Ayala. E ansi fincò este nombre ala tierra para s(iem)pre. E deste donadio le fizò sus cartas, que fue andados dos años empues que fizò la pleytesia en Burgos quando se llamò Rey de Castilla ${ }^{30}$.

Así lo expone Fernán Pérez de Ayala al comienzo de su tratado, transcrito por Pellicer y Salazar.

Evidentemente, esta historia carece de todo rigor y verosimilitud. Lo más llamativo es, por supuesto, esta explicación etimológica, tan del gusto medieval, del término geográfico Ayala a partir de la misma posesión por merced regia. Pero el mismo personaje del infante, las relaciones políticas entre los dos reinos y la cronología de las fases repobladoras carecen de verosimilitud: no hay constancia de ningún hijo de Sancho Ramírez con este nombre, los contactos entre los inmediatos sucesores de Fernando I

3) RAH. Col. Salazar, B-98, fol. 3 y 3 v. 
de Castilla y la naciente monarquía aragonesa fluctuaron constantemente entre el enfrentamiento y los apoyos puntuales ${ }^{31}$ y la repoblación de tierras alavesas puede datarse en el siglo IX, por lo tanto unos 200 años antes del reinado de Alfonso VI y la fecha de 1074 que deja traslucir el texto para la merced real ${ }^{32}$. Además, un tal Lope Vellacoz, que podría identificarse con el hijo de don Vela, se atestigua ya en 1040 dominando la salida al puerto de Colindres y el valle burgalés de Mena ${ }^{33}$. Incluso la ceremonia de armar caballero recuerda demasiado a la célebre de 1330, donde participó el mismo tratadista, dentro de los actos solemnes que rodearon a las fiestas de la coronación de Alfonso XI.

Sin embargo, la invención del infante don Vela no surge de la nada, sino que resulta del cruce y confusión entre varias personalidades históricas y tradiciones locales.

\section{a) Los condes castellanos y' alaveses}

Fntre la Alta y Plena Edad Media existe constancia de varios grandes nobles con este nombre, algunos de ellos emparentados entre sí. Los que más directamente pueden haber servido de modelo al príncipe aragonés son la estirpe de los Vela, que alcanza una posición preponderante en tierras alavesas entre el siglo IX y comienzos del XI, un Veila Obeicoz, senonor palentino anterior a 1012, y un Vela Velázquez, dignidad condal de los territorios leoneses en tiempos de Alfonso VI y por lo tanto contemporáne(o) al presunto asentamiento en sus dominios del ancestro de los Ayalat ${ }^{\text {b. }}$. Fste último podría asimilarse al personaje del mismo nombre de

"Asi, según Zurita, durante los mandatos respectivos de Alfonso VI y Sancho Ramirez en Castilla y Aragón se pasa de un primer momento de colaboración tras la conquista de Toledo a la alianza castellana con el reino musulmán de Huesca, que don Sancho proyectaba conquistar. I. Zlerta, Anales de la Corona de Aragón, t. I (ed. de A. Canellas Lopez, Zaragoza, 1907), pp. 95-90 y 100. En estas circunstancias, hubiera sido ilogico la acogida y favor duradero del primer monarca al príncipe.

$\because$ Ia Rafael FloRANEs senaló varias incongruencias de esta historia, y entre ellas la de la cronologia de la población de Álava, en "Memorias del santo conde don Vela. XI señor del Estado y Casa de Ayala, a la mitad del siglo xI". RAH. Col. Floranes, 9/5089.

: Micala I. Ponthla. Quejana, solar de los Ayala. Vitoria, pp. 6-7. Hay que advertir que, junto a datos históricos de indudable interés, este opúsculo contiene errores en los intentos de equiparar los datos documentales con la genealogía estudiada aquí.

3 Para los datos históricos sobre el conjunto de estos nobles, véase el bien documentado estudio de Jaime de SALAzAR ACHA, "Una familia de la Alta Edad Media: los Vela y" su realidad histórica”. Estudios genealógicos y heráldicos. 1, (1985), pp. 19-64. La 
pila al que la Primera Crónica General atribuye la repoblación de Salamanca por encargo del soberano ${ }^{35}$. Enlaza, por tanto, con el pretendido hijo de Sancho de Aragón en esa actividad tan característica del período comprendido entre 1060 y 1200 aproximadamente, en su vertiente planificada por el monarca y los grandes señores. Hay que resaltar, además, que aunque al don Vela aragonés no se le asigne explícitamente el título de conde, las referencias de los tratadistas de los Tiempos Modernos a un santo señor de esta zona, con este nombre y dignidad, parecen recoger una fama generalizada de que poseía tal condición. Con todo, esta creencia puede haberse elaborado posteriormente en base al título que Fernán Pérez adjudica a su hijo y sucesor y, sobre todo, a una confusión con el personaje mítico que va a ser presentado en las líneas inmediatas.

\section{b) El legendario conde don Vela}

Esta figura aparece en todos los grandes tratados históricos castellanos de los siglos XIII y XIV. Sus rasgos fundamentales se pueden sintetizar en los siguientes: la negativa de un noble y gran propietario de Álava a aceptar la hegemonía en la zona del famoso conde Fernán González; su exilio al Islam español ante el acoso del castellano; el apoyo que presta a los califas y luego a Almanzor para derrotar a la monarquía astur-leonesa; el perdón posterior por los poderes cristianos, con el consiguiente retorno de posesiones; la renovada hostilidad entre sus hijos y los sucesores del conde, que se resuelve en el asesinato de uno de ellos, el infante García, protagonista de un abundante ciclo de romances.

Evidentemente, toda esta historia no tiene ninguna base real. Sus incongruencias son abundantísimas desde el punto de vista cronológico, tanto por lo que atañe a la excesivamente dilatada vida del personaje principal como a las campañas militares y sus protagonistas". Pero si se

contraposición entre leyenda y realidad ha sido brillantemente trazada por Gregorio DE BALPARDA, Historia crítica de Vizcaya y sus fueros, t. II (Bilbao, 1933-34), pp. 36-49, 8291, 136-147 y 154-157.

35 Primera crónica general de España que mandó componer Alfonso X el Sabio y se continuaba bajo Sancho IV en 1289 (ed. de Ramón Menéndez Pidal, t. II, Madrid, 1955), p. 617.

36 Ya Floranes puso de relieve que varias de las derrotas datadas en tiempos de Fernán González fueron, en realidad, posteriores a su fallecimiento. "Memorias del santo conde don Vela..., fol. 158 r. y v. Véase también sobre estas campañas José Manuel Ruiz ASENCIO, "La rebelión de Sancho García, heredero del Condado de Castilla", Hispania Sacra, XXII (1969), pp. 31-37. 
despoja a los acontecimientos de sus caracteres concretos, lo que permanece es la imagen de una trayectoria que debió de ser bastante común en los períodos inicial y medio de la conquista hispana frente a Islam: un noble expulsado de sus territorios que actúa como mercenario de los musulmanes y posteriormente recibe nuevos honores por el retorno al servicio de los cristianos. El modelo ejemplar de estos individuos es El Cid, que destaca de los demás por su constante fidelidad vasallática, enfatizada en el Cantar y, sobre todo, en que logró conquistar el reino de Valencia, que puso bajo la soberanía última de Alfonso VI.

Los avatares del conde traidor y sus herederos se enmarcan, asimismo, en un telón de fondo verídico: las tensiones por la hegemonía que durante los siglos X y XI se establecieron entre el naciente condado de Burgos, que aspiraba a extenderse a lo que entonces englobaba Castilla, y los poderes cercanos y, en un espacio temporal mucho más dilatado, entre los reyes leoneses y estos gobernantes castellanos triunfadores.

Es indudable que la leyenda de don Vela, omnipresente en las obras cronísticas durante más de cien años, influyó en la adopción de este nombre para el ancestro de una estirpe identificada con las tierras alavesas. Muy probablemente, había calado en la zona porque, como apunta Balparda ${ }^{37}$, se había erigido en símbolo del particularismo alavés.

Sin embargo, las circunstancias de finales del siglo XIV eran muy diferentes: el parón que había sufrido la conquista tras la toma de la Andalucía Bética había desplazado en la consideración mítica a los guerreros a ambos lados de la frontera. Al mismo tiempo, la unidad castellanoleonesa se hallaba plenamente consolidada. Todo ello, ciertamente, no impide la vigencia de los modelos anteriores ni la difusión que siguieron teniendo los cantares de gesta tradicionales, pero sí debió de dificultar el crear nuevos mitos bajo las mismas bases.

Por otra parte, la sombra del crimen de Rodrigo, Diego e Íñigo Vela se proyectó sobre los linajes que podían estar emparentados con ellos y que incidian en sus servicios a los monarcas castellanos de tal manera que tanto Fernán Pérez de Ayala como los genealogistas de fines del medievo evitaron trazar un vínculo directo.

\section{c) El infante de Aragón}

Independientemente del recurso a las dinastías de otros reinos peninsulares, que fué bastante utilizado en linajes de procedencia extra-caste-

3. G. BalParda, Historia critica de Vizcaya..., pp. 90-91. 
llana o de las comarcas limítrofes, la procedencia aragonesa de los Ayala pudo haberse deducido de los rasgos comunes en los emblemas heráldicos. Consisten en los bastones bermejos con fondo dorado ${ }^{38}$, que ostentaba también la Corona de Aragón a partir de haberse unificado con el condado de Barcelona.

En el período en el que se sitúa la llegada a Castilla del vástago regio, Aragón tenía una importancia política muy secundaria. Puede pensarse, entonces, en un eco lejano de una afluencia de aragoneses posterior en unos decenios y, más concretamente, con ocasión del matrimonio entre la heredera de Alfonso VI y Alfonso I el Batallador.

En el momento contemporáneo al autor, el panorama había cambiado radicalmente. Con la decadencia de Navarra, las Coronas de Aragón y Castilla se sitúan en el primer plano político de los reinos hispánicos, aunque con un auge territorial superior de la segunda. Las relaciones entre ellas se habían estrechado recientemente por el matrimonio entre el aragonés Alfonso IV y una hermana de Alfonso XI y precisamente fué en el palacio del primero donde Fernán Pérez de Ayala conoció a una doncella criada por la reina que habría de ser su esposa ${ }^{39}$. Muy probablemente, haya aquí de nuevo una transposición al pasado de una realidad presente.

Pero la elección concreta de Sancho Ramírez como progenitor del primer antepasado proyecta, por extensión, sobre este último la aureola de mártir por la fé de su supuesto padre. Este rey es recordado en las crónicas por protagonizar un avance cristiano paralelo al castellano ${ }^{40}$. Y, fuera de sus dominios, permanece en la memoria, sobre todo, por el asedio de Huesca, también citado por nuestro tratadista. Allí muere asaeteado, haciendo jurar a sus hijos y a todos sus magnates sobre los evangelios que no abandonarán la ciudad hasta que la conquisten a los musulmanes. Y el cuerpo del soberano permanece insepulto durante todo el asedio en señal del juramento contraído y quizás también en la creencia de que protegería a la hueste durante la lucha ${ }^{41}$.

38 RAH. Col. Salazar, B-98, fol. 3 v. Los implanta el fundador al acceder al dominio y fundar, paralelamente, el monasterio de Respaldiza.

39 Se contiene en el segundo testamento del padre del canciller, datado en Vitoria, 2 de diciembre de 1378 .

${ }_{40}$ ZURITA, recogiendo indudablemente fuentes muy anteriores, dice de él que fué «el que más continuó la conquista y guerra contra los moros y más extendió su reino de todos los príncipes pasados». J. ZuRiTA, Anales..., t. I (1967), p. 73.

41 Primera crónica general.., t. II, pp. 475-476 y Crónica geral de Espanha..., vol. III, p. 258. Estas dos obras califican a Sancho Ramírez de buen rey y esforzado y el Livro de linhagens, que no recoge el final de la historia, de aboo rei e mui leal. Livro de Linbagens do conde D. Pedro, 5B2, p. 114. 
Y con ello Sancho, el segundo monarca aragonés, se sitúa en un nivel simétrico a Alfonso VI, el otro gran campeón de las empresas bélicoreligiosas de la época al conquistar Toledo. Incluso compensa con su heroicidad el incremento en prestigio y dominios del castellano-leonés. Su conducta refuerza la fama de santidad de su hijo.

\section{d) "E a este don Vela le llamaron empues el Santo"}

Abundando en las reflexiones anteriores, cabe recordar el contacto con los santos o la acogida en el paraíso que, en textos casi contemporáneos al analizado aquí, se dispensa a muchos monarcas de la España occidental o a los que, en la práctica, actuan como príncipes territoriales equiparados a ellos, y más concretamente, Fernán González y el Cid. San Millán, Santiago, San Pelayo y San Isidoro pueblan las páginas de la Primera crónica general con sus apariciones en sueños proféticos que anuncian la victoria o bajo forma humana, para participar directamente en la batalla. Por su parte, el conde don Pedro de Barcelos nos asegura en la década de 1340 que el Cid disfrutaba entonces de un puesto entre los bienaventurados ${ }^{42}$.

Hay que convenir, de todas formas, en que los méritos de este don Vela no son primordialmente guerreros, como los de los anteriores. Sus hechos se encuentran en la misma línea de muchos otros gobernantes medievales, que recibieron por ello los calificativos de buenos y piadosos, pero no específicamente el de santo: poblar una tierra, darle fueros justos, erigir una iglesia y amurallar una ciudad. Coinciden también esencialmente con las actividades de algunos seres sobrenaturales, fantásticos que se plasman en una fecunda prosperidad general ${ }^{+3}$.

Con todo, resulta sorprendente que en la temprana Edad Moderna se atribuyeran cualidades milagrosas a los restos de don Vela y de su hijo, enterrados en la iglesia de Respaldiza. La coincidencia en los datos aportados por los diferentes cronistas permite ver que los fallecidos señores continuaban dispensando protección a sus súbditos al responder a sus rezos con el otorgamiento de lluvia en tiempos de sequía ${ }^{44}$. A finales del

+2. "Este Cide Rui Diaz viveo bem; e estes beês que fez som escriptos nas cronicas dos reis; e el é em paraiso "Livro de linhagens do conde D. Pedro, título VIII, p. 136.

th El ejemplo más claro es el de Melusina que, en la versión de Jean de ARRAS, rotura la región de Forez y construye villas y castillos. Jacques LE GOFF, "Melusina maternal y roturadora", en Tiempo, trabajo y cultura en el Occidente medieval (Madrid, 1983), pp. 289-311.

t4 Antonio DE BARAhona, cronista de Carlos V, expone en su Libro de linaxes y blasones que oy desir al cura que esta alli que cuando no lluebe en aquella tierra 
siglo XVI, época en la que los relatos genealógicos incrementan sus aspectos fantásticos, un descendiente de la Casa recalca la imagen de santidad al añadir a la lluvia y al castigo divino a los incrédulos el que se hubiera encontrado incorrupto el cuerpo del fundador ${ }^{45}$.

Las obras benéficas de quienes habían abandonado la vida terrenal recuerda el cuidado y protección que seres maravillosos, como Melusina, siguen dispensando a sus hijos tras su partida th y permiten ver aquí una concrección sobrenatural del carácter de paterfamilias con el que se reviste al señor de la Edad Media y el Antiguo Régimen. Por otra parte, el conjunto fantástico que forman la lluvia tras las rogativas, la muerte para los incrédulos e irrespetuosos y la conservación del cadáver hace pensar en una religiosidad popular que podría resultar del cruce con una tradición o culto anterior.

De cualquier forma, y como ya se ha apuntado, este enaltecimiento del cabeza de linaje por la santidad resulta muy llamativo, pero enteramente secundario dentro de los modelos nobiliarios. No se registra para otras familias, salvo en el caso ya citado del Cid, y desaparece completamente en las versiones posteriores del origen de los Ayala.

\section{e) El prohijamiento por Alfonso VI}

La mención textual de la crianza del hijo del rey aragonés por el gran monarca castellano hay que entenderla en el sentido que tenía esta expresión hasta fines del medievo ${ }^{47}$ : el establecimiento de unos lazos de parentesco ficticios que aproximaría esta clase de relación a la filial. Esta

\footnotetext{
vienen alli en pro çession y descubren los guessos que lluego luebe y tienen en esto mucha devoçion". Agrega, además, que unos diez años antes habían muerto dos clérigos por tomar tierra del lugar y burlarse de esta historia (Copia del siglo XvII conservada en la BNM. Ms. 11.761, fol. 73 v.).

45 Luis Miguel de AYALA, hijo mayor de don Anastasio de Ayala y Rojas, conde de Salvatierra fallecido en 1588, detalla en su Suma y Brebe Relaçion de los señores y señoras que an suçedido en el señorio y casa de Ayala el rezo de responsos ante los dos sepulcros que llevaban a cabo los habitantes de la zona, la muerte fulminante, en 1540, de un presbítero que quitó una telaraña del rostro del infante y el hallazgo, con esta ocasión, del cuerpo incorrupto de éste. (BNM. Ms. 3087, fols. 23 v. y 24).

46 Jean D'ARras, Melusina o la noble bistoria de Lusignan (ed. de Carlos Alvar, Madrid, 1983), pp. 197-198.

47 En el siglo xv, se incorpora además otro significado, más próximo al del criado actual, para aquellos servidores que sólo estaban con el señor un corto período de años que se podría cifrar, por término medio, en unos siete.
} 
interpretación queda reforzada por el hecho de armarle caballero y la promesa, luego cumplida, de concederle una heredad.

En la historia política del reino de Castilla inmediatamente anterior a los supuestos hechos puede verse un cierto antecedente de este prohijamiento, aunque referido a Navarra y teniendo a consanguíneos por protagonistas. Consiste en la anexión temporal de este reino por Fernando I de Castilla tras haber causado la muerte y derrota del rey, su hermano. La mayor parte del territorio es entregada posteriormente al heredero directo y, según la Crónica de 1344, otro de los hijos del fallecido reclama también los bienes paternos alegando que su tío los disfrutaba en concepto de tutela de bienes de menores ${ }^{48}$.

\section{El PRIMERO DE LOS GUEVARA COMO ANCESTRO SECUNDARIO}

La importancia dada por los Ayala a su enraizamiento con los Guevara se hace notar en que son los únicos afines a los que se dota de un antepasado mítico, situándolo, además, en el mismo estadio cronológico de don Vela. En este caso, el origen remite a un vago eco de la leyenda artúrica: "En t(iem)po del Rey D. Sancho de Aragon que finò sobre Guesca habie un Rico-Ome en Navarra que se llamava $D$. Ladron, que venie de padre en padre de los Reyes de Bretaña. E este era señor de Guevara e de la tierra de Oñate e mucho bueno..." ${ }^{49}$.

Esta reivindicación bretona pudo haberse basado en el empleo en los emblemas heráldicos del armiño, que también era ostentado por los duques de Bretaña. Fernán Pérez de Ayala data su comienzo en la divisa adoptada por un bisnieto de don Ladrón, cuya existencia se constata de manera efectiva entre las décadas de 1130 y 1150. El desgajamiento de varias Casas autónomas en la tercera generación posterior es representado aqui por la entrega paterna de heredades y escudo propio a cada uno de los hijos y una de las soluciones practicadas es la mezcla de panelas azules $\mathrm{y}$ armiños.

El uso de estos motivos está enraizado en tierras navarras y alavesas y con una cronología que se corresponde básicamente con ésta, aunque muy probablemente la datación de la divisa sea excesivamente temprana.

\footnotetext{
* Asi comienza su reclamación Muno Fernando, hijo de don García de Navarra, a su tío Fernando de Castilla: "Senhor rey dom Fernado, seja vossa mercee de vos acordardes de my e me dardes a terra que vos meu padre leixou e guarda. Crónica geral de Espanha de 1344, p. 243.

to RAH. Col. Salazar, fol. $8 \mathrm{v}$.
} 
De manera general, el armiño se atestigua en las armerías de Europa Occidental a partir de 1190-1195. En la forma acuartelada que menciona el documento era portado por un Guevara a partir de 1270. En fondo de gules, el armiño es común también a algunos linajes pamploneses y a los Arazuri, entrocados con la citada parentela.

En cambio, la identidad con los titulares del ducado bretón parece, una vez más, una transposición al pasado de usos contemporáneos a la fuente escrita. De hecho, este motivo heráldico no llega a Bretaña hasta comienzos del siglo xiII y no se convertirá en símbolo del estado ducal más que a partir de 1316, cuando un cambio de armerías le coloca en el lugar central del escudo. En la época posterior, la importancia de los duques relega a segundo plano la existencia de emblemas iguales en otros linajes. Sin embargo, cala profundamente la identificación de este animal con las armas imaginarias del caballero Tristán, el célebre enamorado de Iseo o Isolda, aunque en realidad fuera reproducido frecuentemente con otros emblemas ${ }^{50}$.

En cuanto al peso de lo artúrico propiamente dicho, no conocerá un cierto auge en el reino castellano hasta el siglo XV. Y aún entonces su huella en la antroponimia de los Guevara se reduce, según los datos actualmente conocidos, a un caballero joven registrado en torno a 1470 y que se denominaba Tristán.

Sin embargo, hay que tener en cuenta que este linaje se encontraba ubicado entre dos áreas geográficas donde estas influencias fueron particularmente intensas: el País Vasco y Navarra. La primera reune, junto con Galicia, la mayor cantidad y variación de antropónimos. Éstos se implantan, además, en una etapa cronológica muy anterior a la del resto del reino y que se puede datar ampliamente en los años centrales del siglo XIV. Por lo que atañe a Navarra, es muy frecuente la elección en el mismo período de estos nombres de pila para los bastardos y otros miembros de la dinastía regia ${ }^{51}$.

50 Michael PASTOREAU, "L'hermine: de l'heraldique ducale a la symbolique de l'Etat", en 1491, la Bretagne, terre d'Europe (ed. de Jean Kerhervé y Tanguy Daniel, Brest, 1992), pp. 253-265.

51 Isabel BECEIRO PITA, "Modas estéticas y relaciones exteriores: la difusión de los mitos artúricos en la Corona de Castilla (s. XIII-comienzos s. XVI)n, En la España medieval, 16 (1993), pp. 135- 169. 


\section{EL CARÁCTER DE ENCRUCIJADA DEL DOMINIO}

Los enclaves originarios del señorío se sitúan en una de las zonas en que más confluyeron a lo largo del medievo hispánico diversas aportaciones políticas, institucionales, demográficas y culturales: el sur del País Vasco y La Rioja. En efecto, los valles de Ayala y Orduña, donde se documentan los primeros Salcedo-Ayala, constituyen la prolongación oriental del valle de Mena, es decir, del núcleo de la Castilla primitiva. Y, ya en los inicios del avance de los reinos cristianos, formaba parte del condado de Castilla, pero en los límites con el de Álava ${ }^{52}$. Por lo que respecta a los Guevara, su solar está enclavado en una parte del área alavesa mucho más próxima a Navarra, lo que quizás explique sus líneas de expansión que, desde el temprano siglo IX, aunan el ejercicio del condado alavés con el incremento de cargos y patrimonio en el reino navarro ${ }^{53}$.

En un radio espacial más amplio, el sur de Vascongadas y La Rioja, aparecen sometidas a la doble influencia de Castilla y Navarra. Y, precisamente, en el saber erudito, al menos hasta el siglo XII, es donde más claramente se revela el cruce de influencias múltiples: a las predominantes de Castilla y Navarra hay que sumar las de los restantes focos de la España cristiana, entre las que destacan la mozárabe andaluza y la pirenaica, en especial la del Alto Aragón ${ }^{54}$.

¿ Qué huella han podido dejar estos factores en el texto del padre del célebre letrado y canciller? La más visible se refiere a la cronología de la fundación del dominio por don Vela, que se corresponde parcialmente con la invasión de Álava por Alfonso VI y con el incremento de la actividad repobladora en estas mismas décadas finales del siglo XI.

Por su parte, la procedencia aragonesa del infante trae a la memoria el reparto de la mayoría de Navarra entre Aragón y Castilla en las postrimerías de la centuria siguiente y el conocimiento que existía en algunas abadias cercanas al solar originario de las genealogías de los soberanos del oriente peninsular.

En cuanto a los descendientes, la situación próxima de los dominios de Ayalas y Guevaras a los principales poderes hispanos les permite

52 Rosa M." MARTínez OchOA, "Aspectos de la ocupación del espacio en los valles de Ayala y del Bayas en los siglos $\mathrm{IX}$ al XI", en Vitoria en la Edad Media. (Actas del I Congreso de Estudios Históricos en conmemoración del 800 aniversario de la fundación de la ciudad. Vitoria, 21-26 de setiembre de 1981) (Vitoria-Gasteiz, 1982), pp. 265-283.

53 M." Rosa Ayerbe, "Los Guevara en Álava (Aportación al estudio de la nobleza alavesa bajomedieval)., en Vitoria en la Edad Media..., pp. 369-383.

${ }^{5}$ Manuel C. DiAz Y Díaz, Libros y librerias en La Rioja altomedieval (Logroño, 1979). 
prestar vasallaje a unos y a otros, diversificar entre los tres la búsqueda de fortuna de los diferentes personajes e incluso simultanear, en veces, el ejercicio de cargos otorgados por las coronas castellana, navarra y aragonesa.

Los vínculos con lo vasco se hacen patentes, de forma primordial, en el atribuir a los colonizadores esta procedencia junto con la de Castilla, en los mencionados lazos de afinidad y en las alusiones concretas a las luchas de bandos bajomedievales. Sin embargo, llama la atención el que no se haya erigido como primer ancestro a un ser sobrenatural o maravilloso, emparentado o no con grandes figuras de la historia nacional castellana. Este tipo de fundadores de linajes se registra, en ocasiones, en relatos genealógicos provenientes del norte peninsular ${ }^{55} \mathrm{y}$ tienen como ejemplo más acabado a los Haro que reunen en sí tres clases de ascendencia: la sangre real, a través de un supuesto hermano del rey de Inglaterra, la leyenda histórica castellana, en la filiación por línea directa femenina de uno de los imaginarios jueces de Castilla, y, en la tercera generación, la dama del pie de cabra. Esta última se vincula al ciclo mítico de lo vasco, transmitido por vía oral, y está emparentada, a la vez, con la tradición melusiniana ${ }^{56}$.

A pesar de la afinidad entre los Haro y los antepasados de los Ayala, el escrito de Fernán Pérez no hace la menor referencia a estos pretendidos orígenes de sus aliados que, sin embargo, ya se habían incorporado unos cuarenta años antes al varias veces citado nobiliario portugués. Como ya se ha apuntado, la causa probablemente resida en el afán de que las noticias sobre el linaje de los señores de Vizcaya, mucho más relevante por entonces, no deje en segundo plano ante el posible oyente o lector a los ancestros que se han erigido como motivo de encomio.

Además, el asentamiento de la familia en tierras alavesas y, posteriormente, también en las de Murcia y la meseta sur, no conlleva, como ocurría con los señores de Vizcaya, la necesidad de buscar un arraigo en el territorio subsumiendo los mitos orales vascongados. En su caso, y así se ha intentado mostrar anteriormente, el proceso de identificación se consigue al tomar y reelaborar el tema del conde don Vela. Sin em-

$55 \mathrm{Al}$ menos, las cinco narrativas de fondo mítico incluidas en el Livro de linhagens do conde D. Pedro y estudiadas por Jose Mattoso no se adscriben a la tradición portuguesa sino que las cuatro más fantásticas pertenecen a la vizcaína y gallega. Narrativas dos livros de linhagens, ed. y comentarios de Jose MATToso (Vila da Maia, 1983), pp. 65-73.

56 Jose Ramón Prieto LASA, "Significado y tradición de un relato mítico. Los orígenes de la Casa de Haro", en RDTP, XLVII (1992), pp. 203- 215 y Las leyendas de los señores de Vizcaya y la tradición melusiniana (Madrid, 1995). 
bargo, los otros dos ingredientes son básicamente idénticos: la filiación regia del infante y el gran hito de la historia del reino de Castilla que significan las conquistas y el avance repoblador de la época de Alfonso VI.

Si la sucintos datos biográficos sobre el príncipe aragonés presentan, con todo, una apariencia realista, los relativos al fundador de los Guevara tienen un eco mucho más legendario. Pero estos últimos hunden sus raíces en una temática proveniente de la literatura escrita de la Europa continental. A su adopción, además de los contactos atlánticos, pudo contribuir la gran incidencia de los elementos franceses en la cultura bajomedieval de Navarra, donde se enclavaba buena parte del patrimonio de esta familia. No hay que olvidar que de 1234 a 1328 el reino permaneció bajo la órbita gala, primero como una especie de tutela y a partir de 1276 en forma de anexión. Con posterioridad, y a pesar de restaurarse una dinastía propia, sigue existiendo una cierta dependencia de la política ultrapirenaica. En las dos décadas inmediatas a la elaboración de esta obra el monarca que entonces gobernaba, Carlos II, se comportó, de hecho, como un príncipe francés, interviniendo activamente en los conflictos internos y externos de ese país y, en consecuencia, en la célebre Guerra de los Cien Años.

\section{LA CADENA DE SUCESORES}

Frente a otras obras posteriores con una temática similar, la estudiada aquí ofrece la peculiaridad de prestar especial relieve a los lazos de afinidad y a las ramas colaterales y femeninas, sin centrarse en la línea troncal. Probablemente tenga como causa la relativamente escasa importancia de esta última, si se compara con la de los linajes más hegemónicos de aquel momento. Pero, sobre todo, hay que tener en cuenta el hecho de que la consolidación del sistema de linajes se había producido en una época muy reciente, que podría corresponder a los inicios de la madurez del autor $y$, por consiguiente, se conserva todavía la conciencia del papel de las parentelas más amplias ${ }^{5-}$. En cualquier caso, a fines del medievo algunos descendientes de los Ayala van a reivindicar esta rama familiar por su entroncamiento con representantes del conjunto de la nobleza penin-

- A mi entender, no se puede afirmar que los linajes, en cuanto organización del parentesco basada en la transmisión inalienable del patrimonio por vía de primogenitura masculina, tomen carta de naturaleza definitiva en Castilla hasta mediados del siglo XIV. Isabel Beceiro PITA y Ricardo CóRdoba DE la Llave, Parentesco, poder y mentalidad.... pp. 88-101. 
sular y con las dinastías de los reinos hispánicos, ya que únicamente queda fuera la del país luso.

Estas alianzas se establecen, segun nos transmite el texto, por dos vías primordiales:

- Uniones con infantes o bastardos regios de Navarra y Aragón. Se pueden ejemplificar en el matrimonio de don Ladrón de Guevara con Leonor Sánchez, nieta por línea ilegítima y femenina del aragonés Jaime I el Conquistador. El cotejo con otras fuentes inmediatamente anteriores pone en duda el rigor histórico con el que se reseñaron algunos de estos enlaces y permite ver el afán del escritor por acentuar los vínculos de consanguineidad entre sus antecesores y estas dos coronas ${ }^{58}$.

- Los entroncamientos en el seno de la nobleza son mucho más amplios. Abarcan parentelas y linajes navarros, vascos, castellanos, aragoneses, portugueses $\mathrm{y}$, en menor medida, leoneses y gallegos. Y, en ocasiones, se incorporan al escrito con la trayectoria de cada una de sus ramas. Al contrario que en el caso anterior, al tratar de algunas de estas estirpes se oculta o disimula el nacimiento extra-matrimonial del fundador o de ciertos miembros significados ${ }^{59}$.

Con respecto a Castilla, y secundariamente a la corona de Aragón, se fundamentan los méritos en una participación destacada en las grandes conquistas contra el Islam. Indudablemente, las hazañas de estos personajes están exacerbadas. Al menos las castellanas debieron de alcanzar mucha menor fama y relieve, pues no son mencionadas en las historias generales hispánicas ni en las crónicas dedicadas a los diferentes soberanos.

En cierta manera, se puede considerar una manipulación el mostrar como grandes hazañas hechos de guerra que no resultaban especialmente extraordinarios. Pero más allá de esta anécdota, el enumerar estas empresas cobra un enorme interés para el análisis de la mentalidad nobiliar de la España medieval, pues nos proporciona los hitos militares que para los siglos XII al XIV proponían los guerreros como argumento justificatorio de su propia existencia y, más concretamente, de la preponderancia de algunos de sus integrantes: en Castilla, la batalla de Alarcos, la conquista de la Andalucía Bética — con los asedios de Andújar y Sevilla- y las tomas

58 Así, el Livro de linhagens do conde D. Pedro no cita como cónyuge de Sancha García, descendiente de García Ramírez de Navarra, al miembro de los Guevara don Vela Ladrón, sino al conde don Pedro de Molina (10 A9 y A10, pp. 151-152).

59 El mismo Livro de linhagens... señala la bastardía de Pero Gomes Barroso, el portugués que constituye el primer antecesor constatado de la madre de Fernán Pérez, ya que detalla que era hijo de un particular y la hija de un escudero (30 A3, pp. 330331). Aquí, en cambio, se explica de él únicamente su calidad de caballero. 
de Cartagena y Algeciras. Por lo que concierne a la corona de Aragón, mucho menos vinculada a la familia, se detalla exclusivamente la anexión de Mallorca.

La otra clase de servicios a los monarcas consiste en el disfrute de los cargos administrativos que varias ramas de la parentela ostentaron en Navarra, Aragón y Castilla. En consonancia con los cambios efectivos en la hegemonía de los reinos hispánicos, a partir de 1230 se recalca progresivamente el disfrute de oficios en el último país, con un cierto menosprecio de los ejercidos en los otros dos.

La finalidad de todo ello es hacer patente ante los futuros receptores del texto la imagen de los Ayala como un linaje peninsular con un fuerte sentido nacional. En efecto, puede aplicarse este último calificativo dentro del concepto que tenían los eruditos medievales y que queda especialmente de manifiesto en San Isidoro, Alfonso $\mathrm{X}$ y los historiadores prerenacentistas del siglo $\mathrm{XV}$. En todos ellos se concibe España como una profunda unidad, equiparable básicamente a la Hispania romana, y que se sitúa por encima de las distintas formaciones políticas.

Este carácter nacional queda resaltado aquí por el exilio voluntario de Navarra de Vela Ladrón para no depender de los soberanos de Francia. Su actitud aparece como una respuesta al matrimonio de la reina Juana con el heredero francés y a la inmediata unión de las dos coronas en 1276: "Este D. Vela Ladrón [...] non quiso haber por reina a D. ${ }^{a}$ Juana ni al Rey de Francia, quando finó el Rey D. Enrique, nin le plugo morar en Navarra, e moro en Aragon onde tenia tierras" " . Con esta frase queda establecida una línea separadora entre un poder, continental, extraño y susceptible de ser hostil y, por otro lado, un ámbito interior, hispánico, en el cual las querellas entre sus monarquías no dejan de tener un cariz doméstico frente a las que puedan trabarse con el mundo ultrapirenaico.

\section{La evolución de la genealogía de los Ayala en el Siglo XV}

La historia elaborada por Fernán Pérez es incorporada entonces a los nobiliarios generales y, en menor grado, a escritos de algunos descendientes dedicados al mismo asunto. Esta difusión acarrea considerables variantes a tenor de las personalidades de los diferentes autores y de los cambios que se producen en los modelos adoptados por la nobleza, en los gustos culturales de la élite y, en parte como consecuencia de lo anterior, en las estructuras y contenidos del relato genealógico. En este último aspecto,

(6) RAH. Colección Salazar, B-98, fol. $12 \mathrm{v}$. 
hay que señalar que a partir de los decenios centrales se pueden advertir los inicios de un afán de rigor histórico, común a la gran variedad de formas y géneros contemporáneos que en el reino de Castilla se ocupan del pasado ${ }^{61}$. Evidentemente, el sentido crítico no domina totalmente, ya que muchos escritos siguen dando cabida a leyendas fantásticas. Pero su valor como autoridad disminuye frente a las crónicas. Y aumenta la necesidad de cotejar diversos testimonios, aunque todavía no se acuda sistemáticamente a los diplomas y otras fuentes documentales.

Con respecto a la historia de los Ayala, este clima se traduce en una cierta incomodidad de los autores que se ocupan del tema a propósito de don Vela y sus datos biográficos. El sentimiento de que su figura está construida sobre errores considerables en la cronología y la filiación hace que algunos autores difuminen el protagonismo de este personaje y otros eliminen los detalles concretos que podrían ser más discutibles. Sin embargo, hasta finales del siglo XVI y comienzos del XVII no se constata un rechazo a este personaje, fundado en la falta de concordancia con los datos que aportan los documentos públicos y privados ${ }^{62}$.

Curiosamente, los sucesores y otros vástagos de la Casa son los que menos utilizan la obra del padre del canciller en sus propios escritos. No es fácil dilucidar si ello responde a una cierta actitud de distanciamiento intelectual por los problemas que se acaban de exponer o si, por el contrario, es precisamente el otorgarle validez lo que conduce a no insistir sobre este procedimiento de exaltación del linaje y buscar otros complementarios.

Por contraste, los tratadistas con pretensiones de lo que hoy calificaríamos de profesionales de la historia son los que proporcionan más indicios sobre el uso y aceptación de los ya establecidos ancestros míticos de los Ayala, ya sea el del conjunto del grupo nobiliar o el de los mismos descendientes.

La utilización por los familiares del texto de Fernán Pérez llega hasta

61 Véase a este respecto Robert Brian TATE, "La historiografía en la Espana del siglo XV", en Ensayos sobre la bistoriografía en la España del siglo XV (Madrid, 1970), pp. 281 y ss., y Pedro M. CÁTEDRA, La historiografía en verso en la época de los Reyes Católicos (Salamanca, 1989), pp. 15-38.

62 A este respecto, es muy sintomático el contraste entre dos escritos anónimos referentes la descendencia de la Casa, copiados en 1596 de textos anteriores. El primero, que parece provenir de un "cuaderno" anterior en unos 15 años, señala las incongruencias cronológicas con unos argumentos muy similares a los que esgrimirá Floranes medio siglo después. El segundo, en cambio, que podría proceder de un original de comienzos del XVI, acepta básicamente al infante como ancestro (BNM. Ms. 704, VIII, fols. 116 v.-122 v. y 123-128. Existen otras dos copias idénticas en BNM. Ms. $841,3)$. 
el mismo Fernando el Católico, quien alaba el linaje de su abuela materna por su capacidad de entroncar con todos los restantes. Ciertamente, dentro de la política de exaltación regia tiene una importancia muy secundaria, tanto por el relegamiento que sufren en este sistema de parentesco las ramas femeninas y segundonas como por el menor poder y riqueza de los Ayala frente a otras ramas de su ascendencia. Pero, en cambio, esta familia aporta como elemento nuevo los lazos con la nobleza del País Vasco y de Navarra. Este ingrediente permite completar la imagen del soberano como pariente mayor de la aristocracia de todo el territorio, tan característica de los comienzos de la Edad Moderna.

\author{
ISABEL BECEIRO PITA \\ Departamento de Historia Medieval \\ Centro de Estudios Históricos. CSIC. Madrid
}

\begin{abstract}
A finales del siglo XIV, el relato genealógico escrito por Fernán Pérez de Ayala sobre la trayectoria de su propia familia contribuye a elaborar los modelos de ancestros míticos para la aristocracia castellana. Inspirándose libremente en las tradiciones locales, traza como elementos principales del antepasado fundador la procedencia regia, los vínculos con las monarquías de Castilla y Aragón, el papel activo en la ocupación del territorio contra el Islam hispánico y la fama de santidad. En la centuria siguiente, la difusión de este relato por otros genealogistas trae consigo importantes cambios temáticos. Pero ciertos indicios hacen suponer que los descendientes de los Ayala continuaron basándose en el texto original para reivindicar la gloria del linaje.
\end{abstract}

At the end of the fourteenth century, the genealogical tale written by Fernán Pérez de Ayala about his own family helped to create the patterns of the mythical ancestors in the castilian Kingdom. The author configurated the biography of the founder with the folowings characters, added to a traditional background: the royal origin, the relationships with the kings of Castile and Aragon, the active role in the fight against the Spanish muslims and the fame of sanctity. A century after, the diffusion of this tale by other genealogists brought together some important transformations. On the other hand, the kinship continues to use the original text to vindicate the proud's family. 